\title{
Research Paper
}

\section{The Role of Parenting Styles, Parental Stress and Executive Functions Deficits in Predicting the Children's Internalizing and Externalizing Problems}

\author{
Seyyedeh Faezeh Khoshkerdar ${ }^{* 1}$, Majid Baradaran ${ }^{2}$, Farzaneh Ranjbar Noushari ${ }^{2}$ \\ 1. M.A. in General Psychology, Payame Noor University, Astaneh Ashrafiyeh, Iran \\ 2. Assistant Professor, Department of Psychology, Payame Noor University, Tehran, Iran
}

Citation: Khoshkerdar SF, Baradaran M, Ranjbar Noushari F. The role of parenting styles, parental stress and executive functions deficits in predicting the children's internalizing and externalizing problems. Quarterly Journal of Child Mental Health. 2020; 7(2): 156-168.

http://dx.doi.org/10.29252/jcmh.7.2.14

\section{A R T I C L E I N F O}

\begin{tabular}{l}
\hline Keywords: \\
Parenting styles, \\
parental stress, \\
executive functions, \\
internalizing and \\
externalizing problems
\end{tabular}

Received: 21 jan 2019 Accepted: 28 May 2019 Available: 21 Sep 2020

\section{A B S T R A C T}

Background and Purpose: The problems of childhood can be generally divided into two large, but overlapping groups of internalizing and externalizing problems. Internalizing and externalizing behavioral problems can negatively affect the different functions of children and adolescents. Present study aimed to investigate the role of parenting styles, parental stress and children's executive functions deficits in predicting the children's internalizing and externalizing problems.

Method: The present research was a descriptive correlational study. The study population included all the male primary school students in district 2 of Rasht city in the academic year of 2018-2019 and their parents. From this population, a sample of 375 students was selected by multistage cluster sampling. They completed Parenting Stress Index (Abidin, 1990), Parenting Questionnaire (Frick, 1991), Barkley Deficits in Executive Functioning Scale (Barkley, 2011), and Child Behavior Checklist (Achenbach \& Rescorla, 2001). Data were analyzed by Pearson correlation coefficient and step-wise regression method.

Results: Findings showed that there was a significant negative correlation between positive parenting, father involvement and awareness and children's internalizing and externalizing problems. It was also found that corporal punishment, poor monitoring and authority had a significant positive correlation with children's internalizing and externalizing problems. Also, results showed that parental stress and children's executive functions deficits (and its components) had a significant positive correlation with children's internalizing and externalizing problems $(\mathrm{P}>0.01)$. Results of regression indicated that executive functions, father involvement, corporal punishment, authority, awareness, positive parenting, and poor monitoring were predictors of internalizing problems, whereas father involvement, executive functions, positive parenting, stress, corporal punishment, emotional self-regulation, awareness, authority, and poor monitoring were predictors of children's externalizing problems $(\mathrm{P}>0.01)$.

Conclusion: Based on the findings of this study, it can be concluded that positive parenting, father involvement and awareness are negative predictors of children's internalizing and externalizing problems, whereas corporal punishment, poor monitoring, authority, parental stress, and children's executive functions deficits are positive predictors of children's internalizing and externalizing problems. Findings of the present study can help to the development and implementation of effective preventive and therapeutic interventions for behavioral disorders in children.

\footnotetext{
* Corresponding author: Seyyedeh Faezeh Khoshkerdar, M.A. in General Psychology, Payame Noor University, Astaneh Ashrafiyeh, Iran. E-mail addresses: Faezekhoshkerdar@gmail.com
} 


\title{
نقش سبككهاى والدكرى، تنيدكى والدين، و نارسايى در كنشهاى اجرايى در ييشينى مشكلات دروننمود و بروننمود كود كان
}

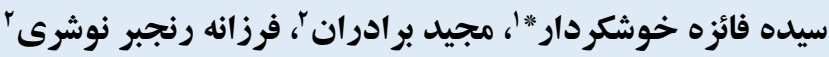

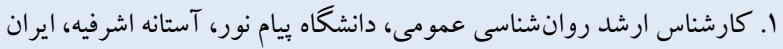

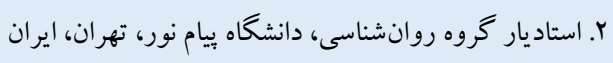

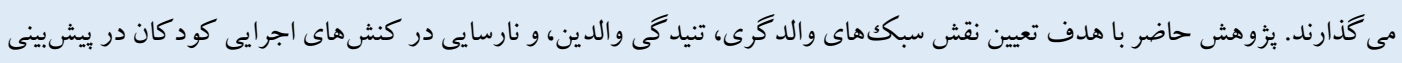

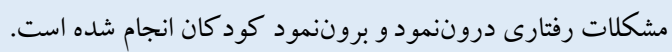

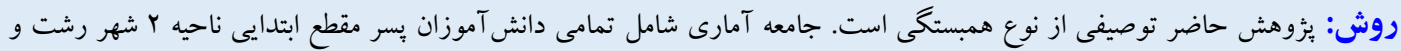

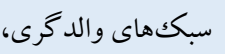
تنيدگى والدين، كنش اجرايى،

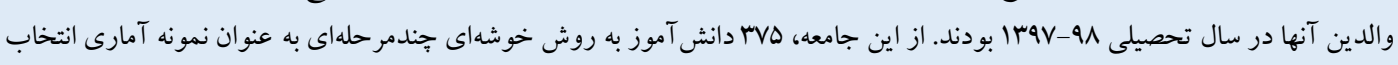

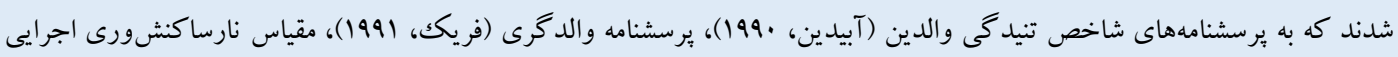

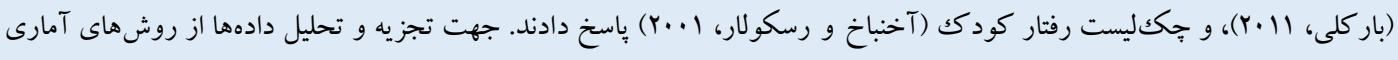
ضريب همبستخى ييرسون و روش ركرسيون كام به كام استفاده شد.

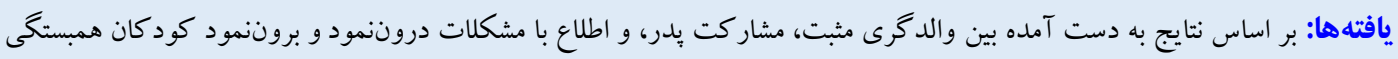

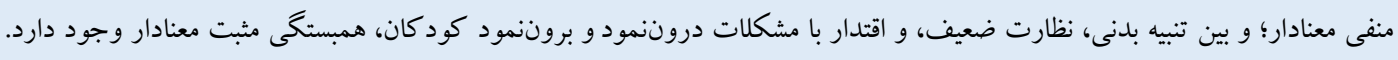

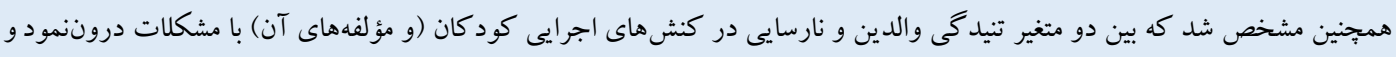

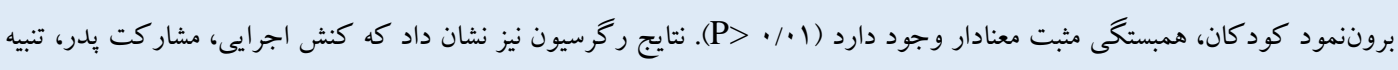

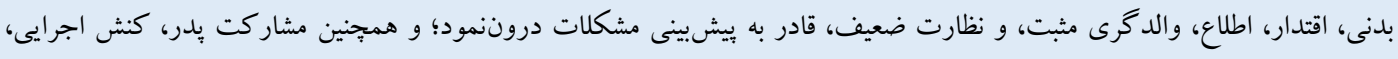

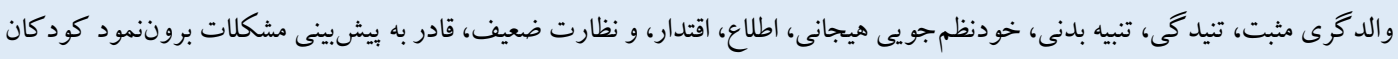

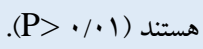

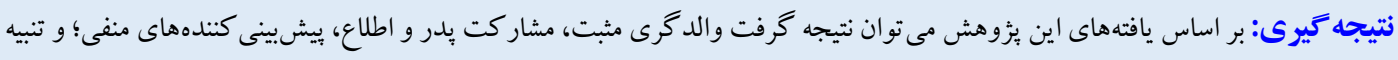

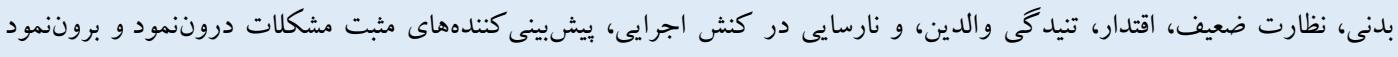
دريافت شده:

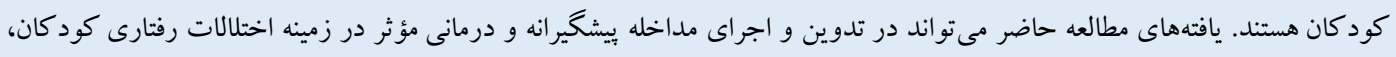


يِيخيرى مى كنند و بر اين باور هستند كه فرد دجار اختلال نيست، بلكه

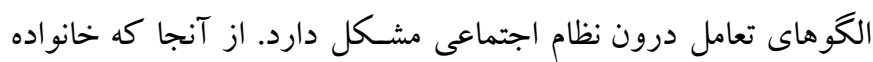

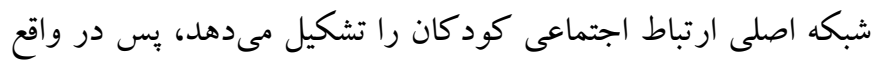

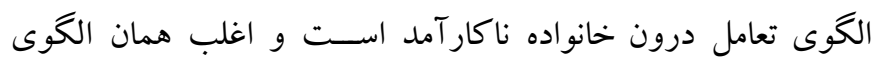

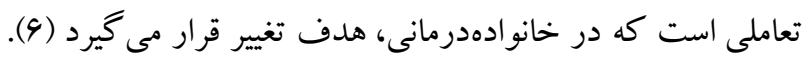

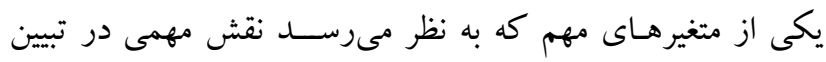

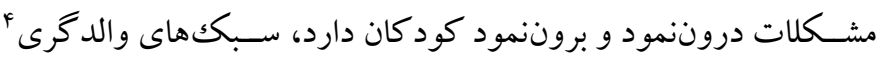

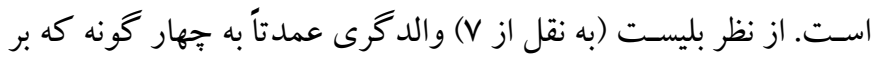

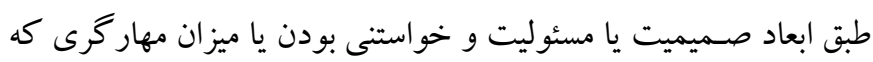

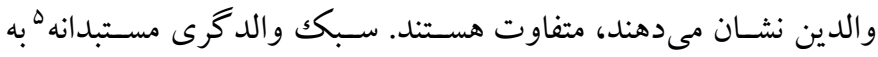
صورت صميميت و مسئوليت كم و انتظارات و مهارگرى زياد مشخص

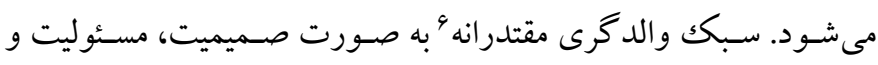

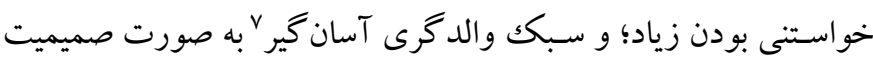

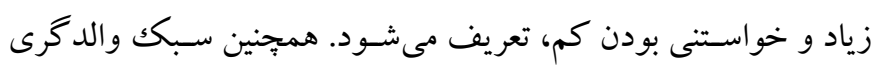
بى توجه، صـميميت و خواستنى بودن كم را شـامل مىشود. ارتباط بين

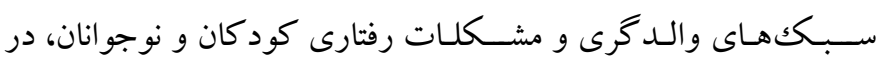

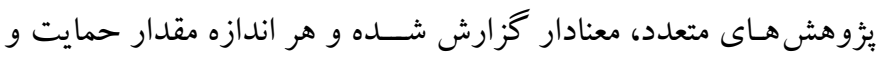

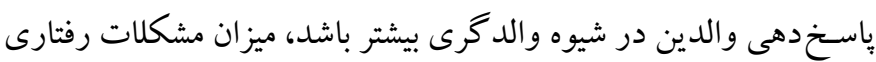

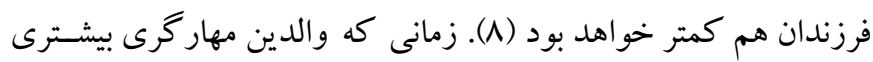
نسـبت به موقعيت داشـته باشـند مى توانند مديريت مؤثرترى در ايفاى

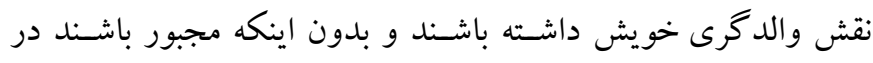
مورد مقررات خود با فرزندانشان مجادله كنند، محدوديتهاى مؤثرى

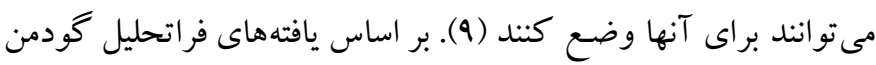

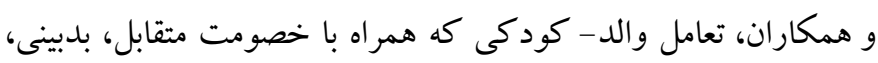
و مهار گرى بيش از حد و خشـونت باشـد، يكك عامل بيش بينى كننده است و در بسيارى از آسيبهاى دوران كودكى دخالت دارد (· (1). اين

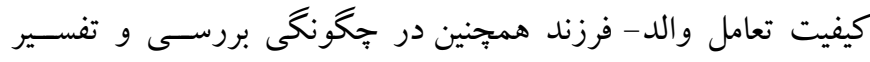
كودك از جهان اطراف خود تأثير گذار است (11).

5. Authoritarian

6. Authoritative

7. Permissive

8. Neglectful
مقلمهه

كود كان به عنوان يكى از گروههاى سـى آسيب بذير در معرض انواع

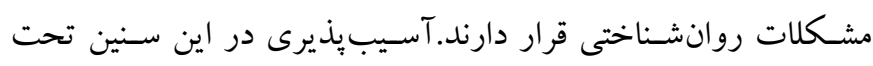

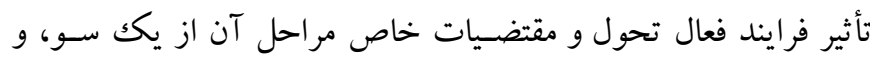

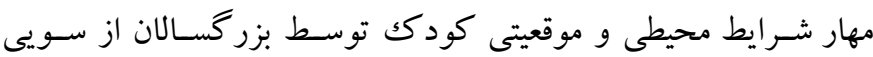

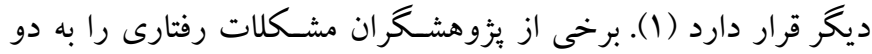

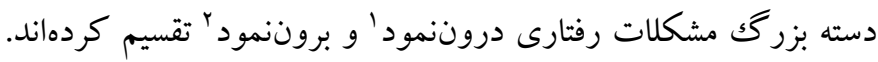
مشكلات دروننمود شامل اختلالهايى است كه نشانهاى بيمارى بيشتر بر خود فرد-و نه براطرافيان- تأثير دارند؛ بنابراين، به خاطر اين ماهيت إنهايت

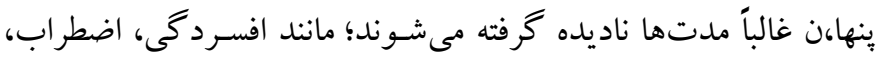

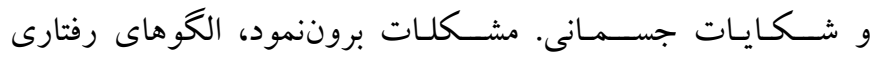
سـازشنايافتهاى هستتند كه به سـمت بيرون از كودك جهت دارند و

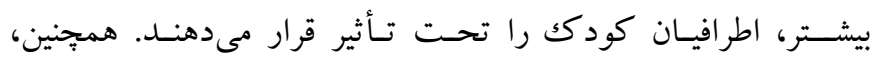

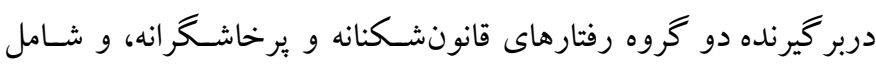

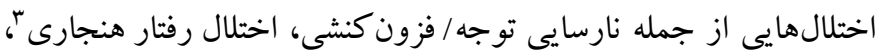
و اختلال نافرمانى مقابلهاى است (Y).

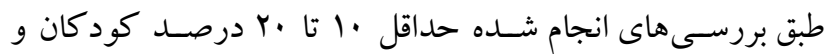
نوجوانان كه در ســين مدرسـه هسـتند، گرفتار مشـكلات قابل توجه و و مـداوم هيجانى يا رفتارى هســتد (ب). ميزان شـيوع اختلالات هيجانى رفتارى در يُزوهش غبارى بناب، يرند، حسـين خانزاده، موللى و نعمتى

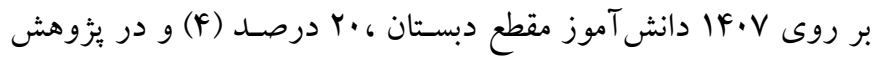

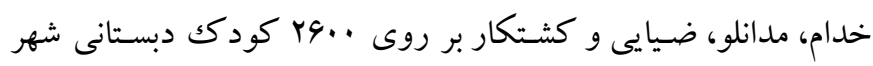

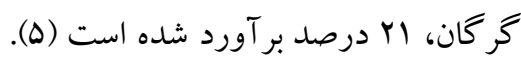
درباره سـبب شـناسى اختلالهاى دوران كودكى، مدلهاى مختلفى نـى

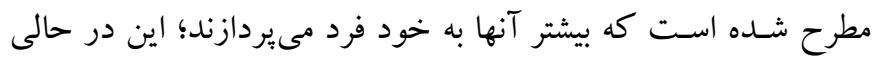
اسـت كه مدلهاى سيستمى كه اثر سيستم اجتماعى اوليه بر كودك و و

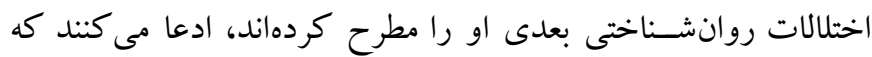

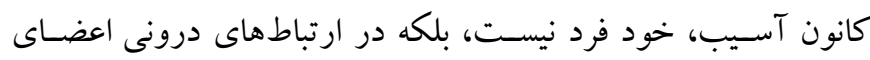

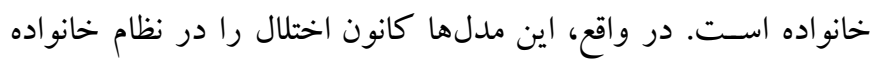

1. Internalizing

2. Externalizing

3. Conduct disorder

4. Parenting styles 
خالق و رونر (19) حاكى از آن است كود كانى كه والدينشان بذيراى

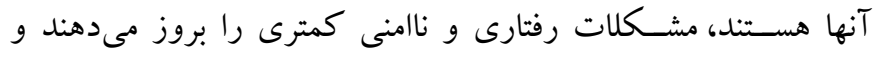

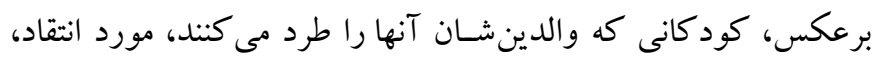

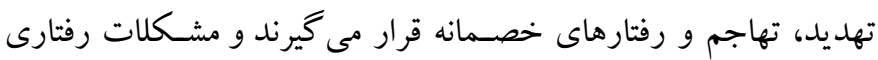

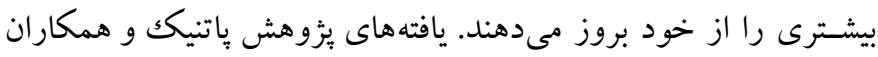

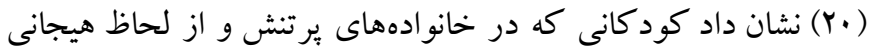
بى ثبات زندگى مى كنند، توانمندى كمترى در حفظ آرامش خود دارند

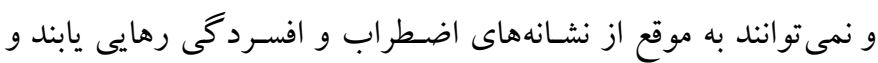
هيجانات خود را تنظيم و مديريت كنند.

طى سـالهاى اخير مشخص شده است كه مغز براى كار كردن مؤثر، نيازمند نوعى سـيستم اجر ايى است كه ساير نظامها، توانايىها و فرايندها

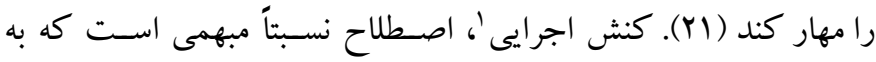
مجموعه متنوعى از تو انايىهاى شـناختى وابسـته به هم اطلاق مىشـود كه به طور استعارى تحت نام اجرايى گرد آمده است (YY).

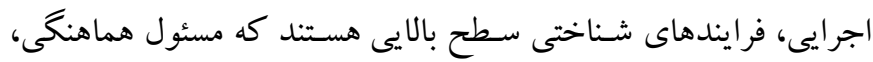

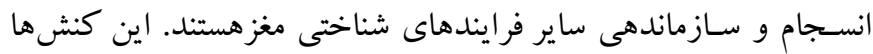

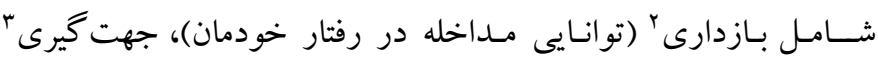

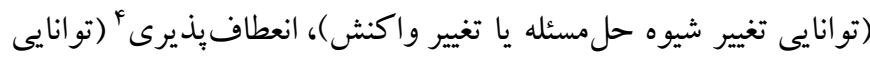

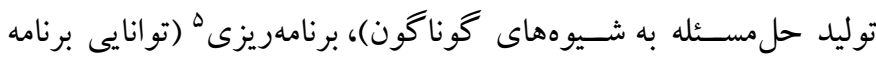

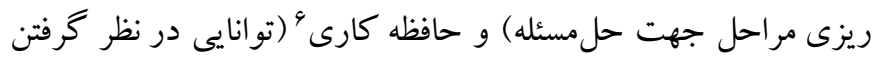

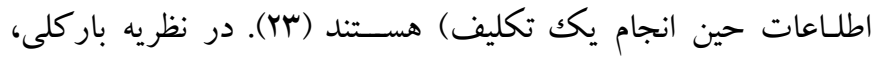
كنش هاى اجر ايى خودنظمده هستـند و بازدارى رفتارى، ضـرورى ترين

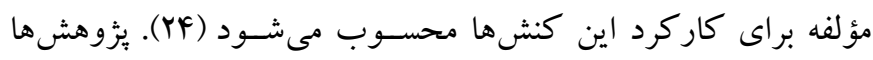

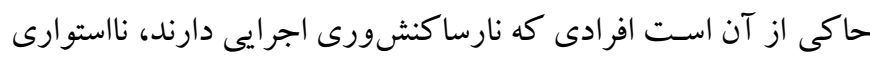

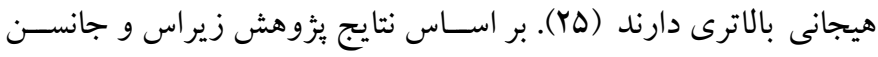

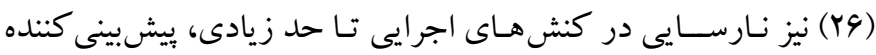
عملكرد تحصيلى و رفتارى دانش آموزان است. بر اسـاس مطالب مطرح شـده فوق و اهميت متغير فردى نارسايى در كنشهاى اجرايى و با توجه به كمبود يُزوهش در اين زمينه، همجينين

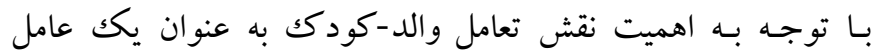

\section{Flexibility}

5. Planning

6 . Working memory
يويو و ايلسـانمى (به نقل از Y I) نشـان دادند كه تعامل منفى والدفرزند كه منجر به كاهش نظارت بر فرزند، نظم و انضباط تنبيهى بيشتر،

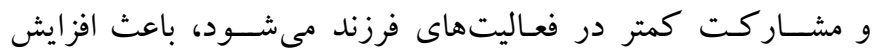

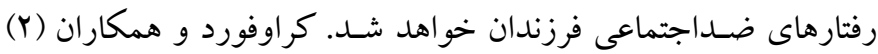
در مدلى كه به منظور تبيين اختلالهاى دروننمود كودكان طراحى كرده بودنـد، دريـافتــد در رابطه غيرمســتقيم بين تنظيم هيجانى و اختلالهاى دروننمود كودكى، عاطفه منفى مادر، نقش واسطهاى دارد.

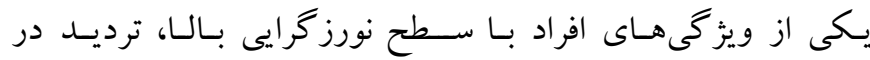

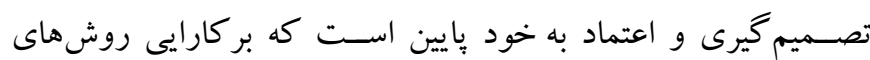

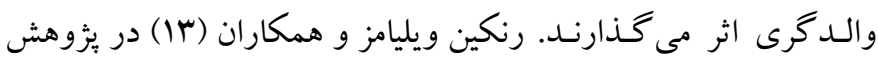

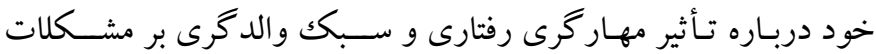

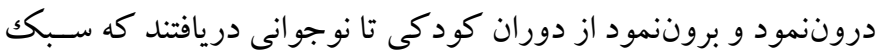

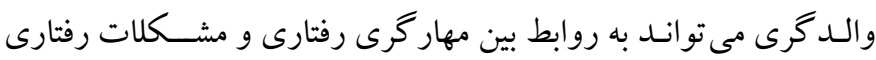
كود كان كمك كند. اكرجه تولد يك نوزاد از لذتبخشترين اتفاقات زندگى هر يدر و مادرى است، اما والد بودن مسئوليتهاى جديد و نقشى متفاوت را براى فرد به ارمغان مى آورد. اين مسئوليتهاى جديد به خودى خود

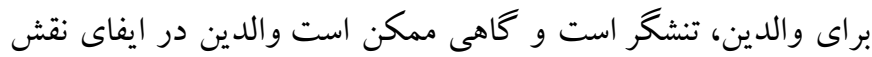
والدگرى خويش، احساس ناكار آمدى كنند. در جنين مواقعى والدين احساس مى كنند كه قادر به مهار شرايط نيستند و اين احساس عدم عدم مهار گرى، تنيدگى بيشترى براى آنها به همراه مى آورد (ع) (1).

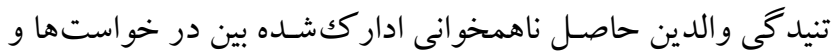
تقاضاهاى والدينى و منابع فردى است؛ اين تنيدگى مى تواند در حيطههاى

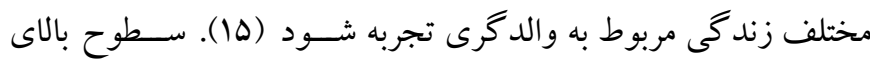
تنيدگى والدين باعث مىشـود كه آنها كرايش بيشـترى به اسـتفاده از

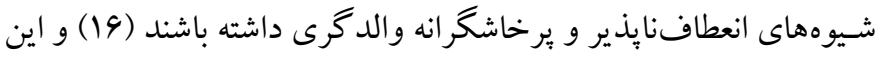

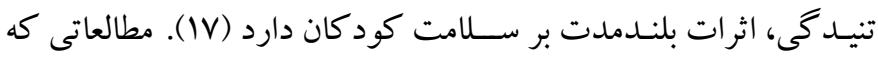

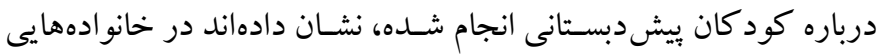

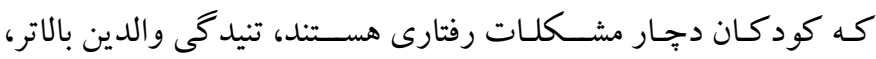
حمايت همسر ان كمتر، و منفى گرايى مادران بالاتر است (1) (1). مطالعات

1. Executive function

2. Inhibition

3. Orientation 
(r سوال)، اقتدار (F سوال) و نظارت ضعيف (F سوال) است كه با هدف

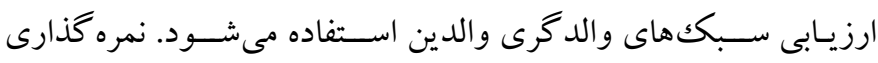

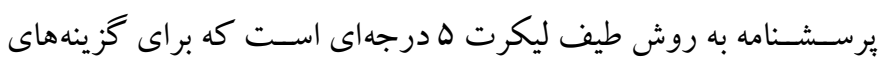
"(هر گز)، (ابه ندرت)، (ابعضى مواقع)، (اغلب)، و (هميشه)) به ترتيب امتيازات

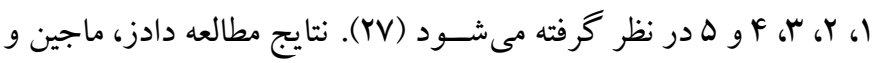

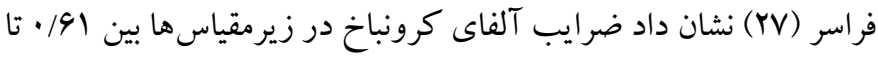

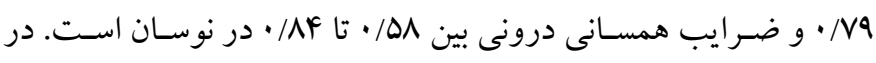

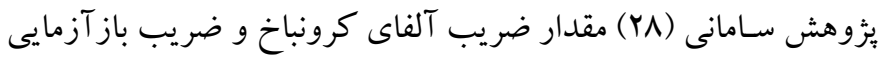

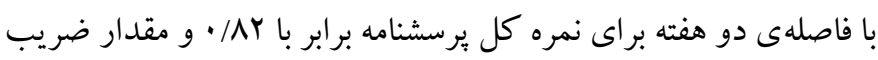

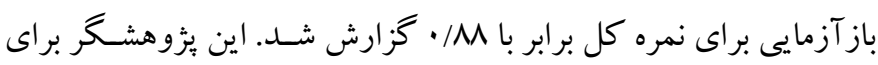

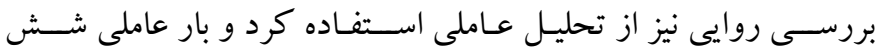

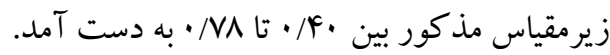
r. شاخص تنيدگى والدين"ّ شاخص تنيدگى والدين توسط آبيدين در

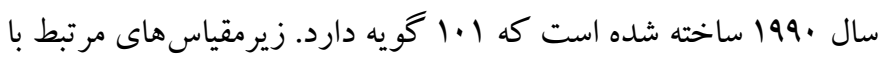

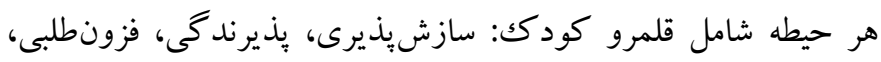

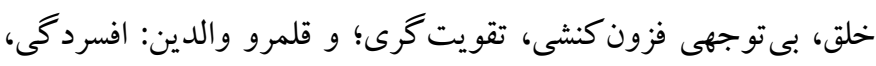

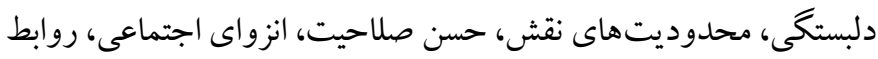

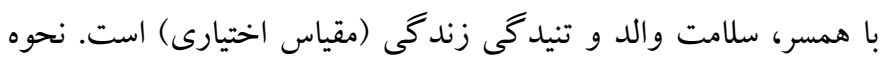

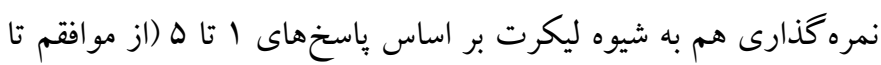

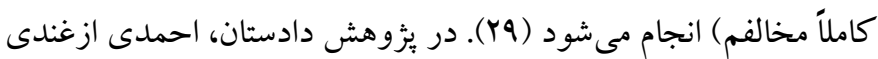
و حسن آبادى (Y9) ضريب همسانى درونى ابزار براى كل مقياس M M/ • و

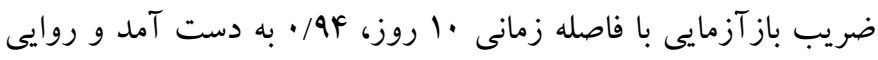

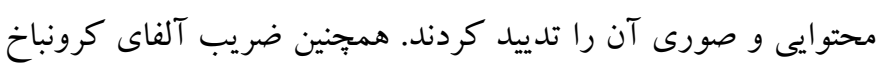

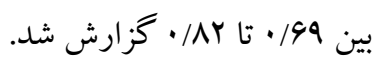
"م. مقياس نارسا يیىها در كنش هاى اجرايى": اين مقياس حاوى اطلاعات

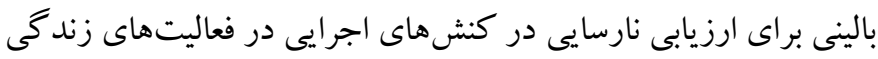

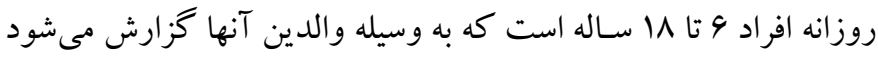

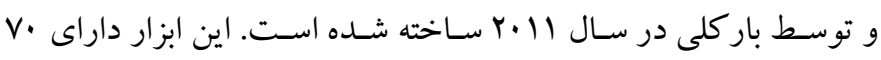

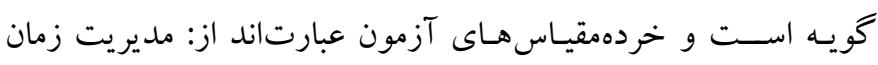

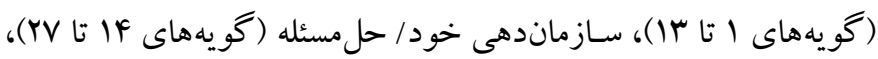

3. Deficits in functioning scale
محيطى كه تأثير زيادى در ايجاد و تداوم مشـكلات هيجانى- رفتارى

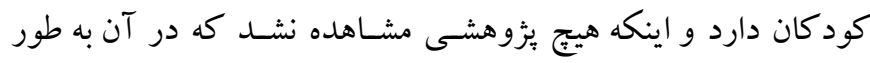

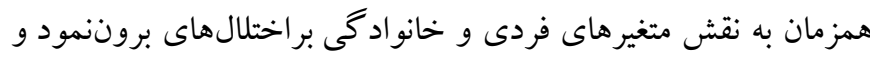

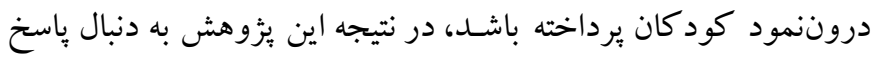

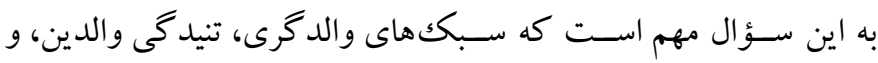

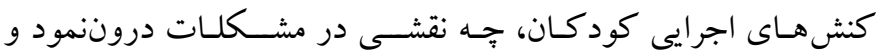
برون بمود كود كان دارند.

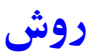
الف) طرح هزوهش و شر كت كنند كان: نوع مطالعه حاضر، همبستخى

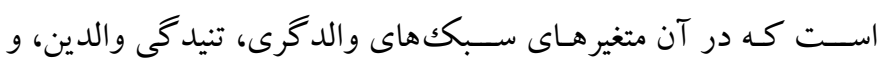
كنشهـاى اجرايى بـه عنوان متغيرهـاى بيشبين؛ و متغير مشــكلـات دروننمود و بروننمود به عنوان متغير وابسته هستند. جامعه آمارى مورد مطالعه .. 19 نفر از دانش آموزان يسر مقطع ابتدايى ناحيه ب رشت در در سال تحصـيلى 1 آموزان از اين جامعه آمارى به عنوان نمونه تعيين شـــند كه والدين آنها

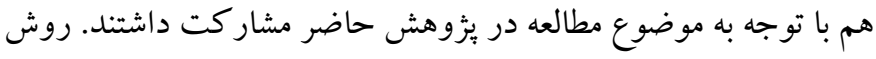

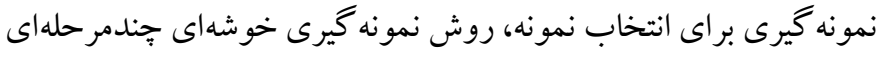

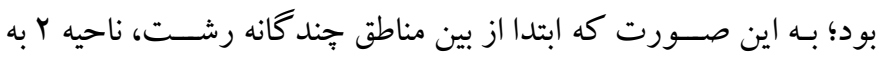
تصـادف، انتخاب شــ؛ سـبس از مدارس ناحيه Y، جهار مدرسه و از اين

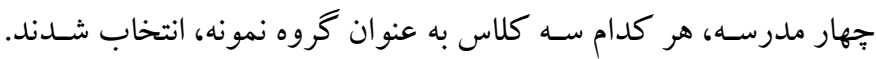

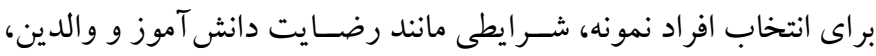

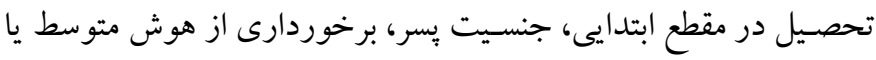

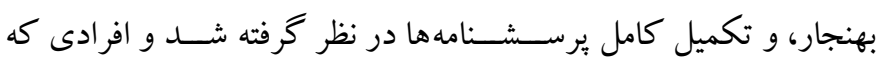

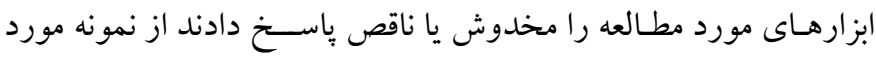
مطالعه حذف شـدند. راى جمع آورى اطلاعات از ابزارهاى زير استفاده

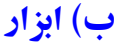
ا. بِرسـشـامه والدكرى آلاباما ' (فرم كودكان) توسـط فريك در سـال

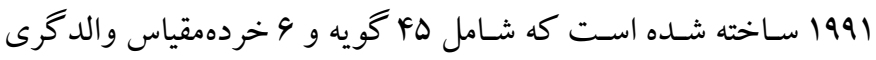
مثبت (V) سوال)، تنبيه بدنى ( •اسوال)، مشار كت يدر (V سوال)، اطلاع 
ج) روش اجرا: بعد از كسب مجوزهاى لازم از اداره آموزش و برورش

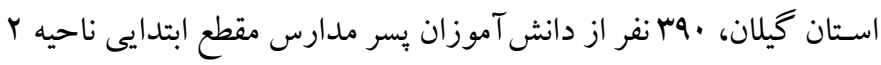

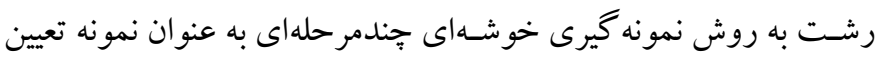

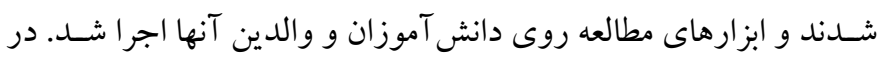

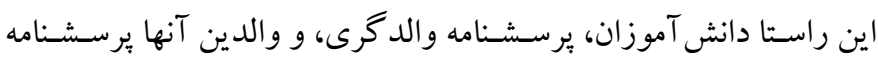

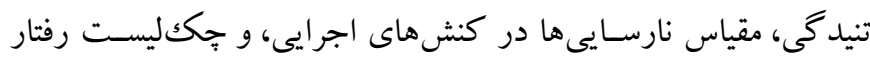

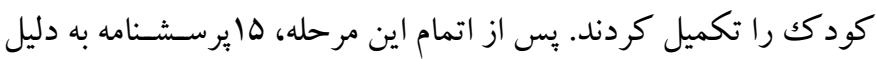

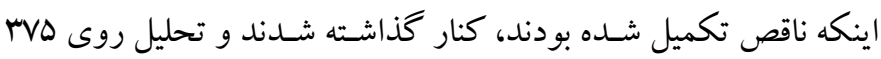

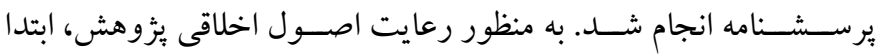

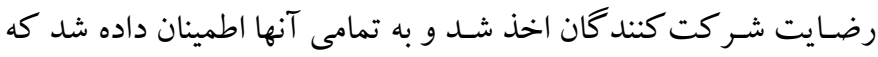

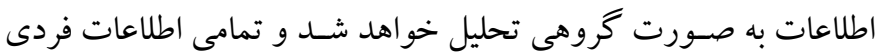

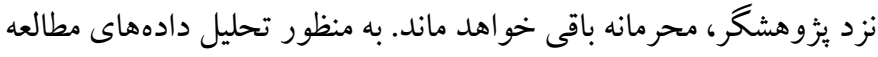
از همبستخى بيرسون و رگرسيون كام به كام استفاده شد.

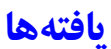
در جدول ا شـاخص هاى توصسيفى متغيرهاى بزّوهش شـامل ميانخين،

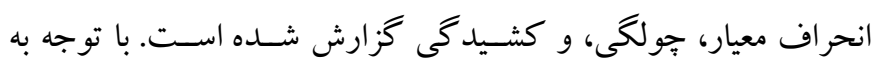

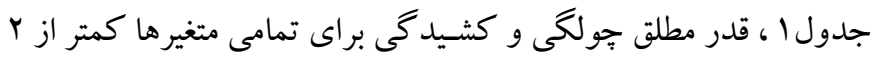

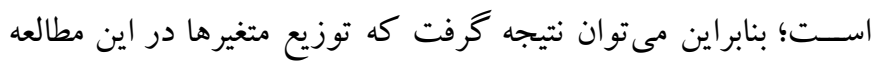

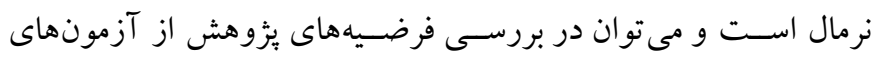

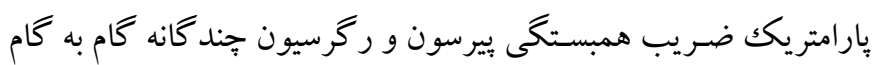

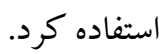

مهار خود (كويههاى Y تا ·F)، خودانگيزشسى (كويههاى أF تا تهF)، و

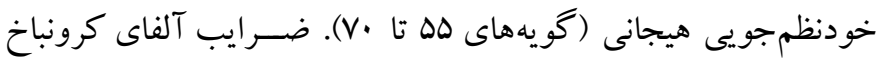

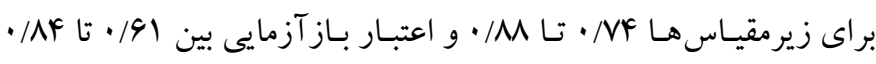

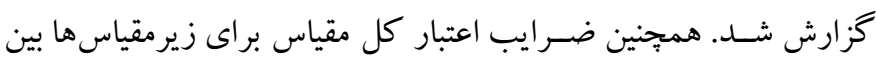

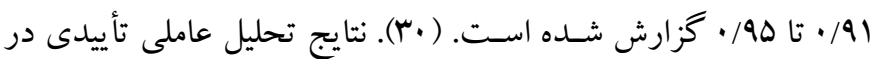
مطالعه مشـهدى، ميردورقى، حسـين زاده ملكى، حسـنى و حمزه لو نيز نشان داده شد كه ضرايب همسانى درونى مقياس بين 194/ تا AF/• است و بنابر اين روايى مقياسف مطلوب است. همجنين ضريب اعتبار برسشنامه دانه

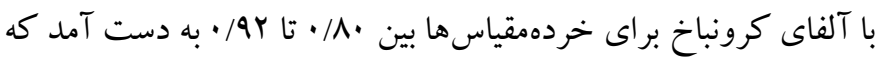
رضايتبخش و مطلوب است (rا).

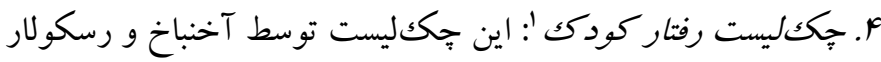

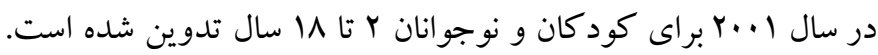

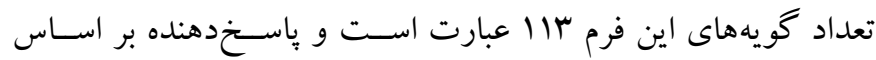

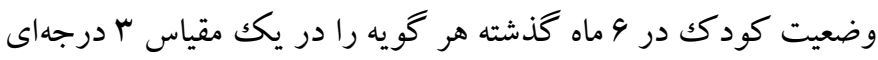

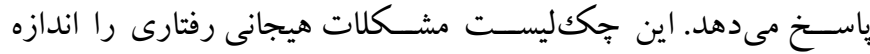

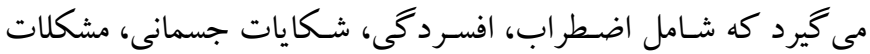
اجتماعى، مشـكلات تفكر، مشكلات توجه، رفتار قانونشكنانه، و رفتار

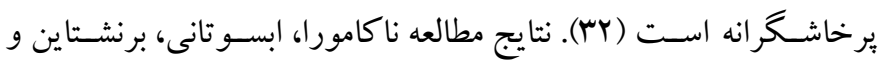

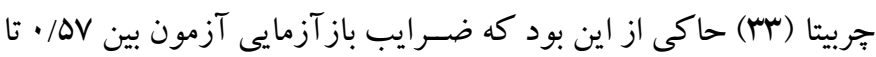

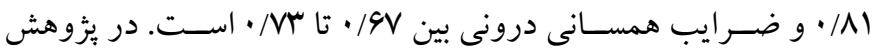
مينايى دامنه ضـرايب همسـانى درونى مقياسها از بو/ • تا ه9/• و دامنه

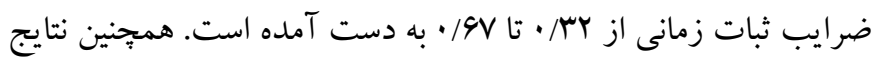

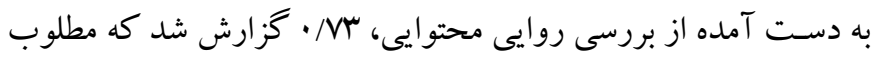

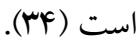

جدول 1: شاخصهاى توصيفى متغيرهاى ثزوهش به تفكيكى تروهها (تعداد= rYo)

\begin{tabular}{|c|c|c|c|c|}
\hline كشيدىى & جولكى & انحرافمعيار & ميانتين & متغير \\
\hline$-1 / \cdot 0$ & $\cdot / T V$ & $|V / A|$ & $F \Delta / V F$ & والدكرى مثبت \\
\hline$-\cdot / 9 r$ & $-\cdot|r|$ & $9 / 19$ & $r V / \Lambda \Delta$ & تنبيه بدنى \\
\hline$-1 / r Y$ & $\cdot / \cdot r$ & N/IT & $r M / 10$ & مشار كت يدر \\
\hline$-\cdot / A F$ & $-\cdot 109$ & Dמי & $\Lambda / \Delta \Lambda$ & اطلاع \\
\hline$-1 / .9$ & $-\cdot / 19$ & $r / 4 \Delta$ & $\mid r / 9 r$ & اقتدار \\
\hline
\end{tabular}




\begin{tabular}{|c|c|c|c|c|}
\hline$-1 / \pi F$ & .1 .0 & $r / l f$ & $\mid r / \Delta 9$ & نظارت ضعيف \\
\hline$-\cdot / v 9$ & $\cdot / 09$ & YN/GY & $r 1 . / 9 \mathrm{~V}$ & تنيدىى \\
\hline$-1 / 4 \mathrm{~A}$ & $\cdot / \mu 1$ & $1 . / 9 r$ & r9/11 & مديريت زمان \\
\hline$-1 / 4 r$ & $\cdot / r F$ & $9 / 94$ & re/ro & حلمسأله \\
\hline$-1 / 1$ & $\cdot / 49$ & $9 / V r$ & $r 8 / 19$ & مهار خود \\
\hline$-1 / T V$ & . & $N / Y_{1}$ & $r \cdot N \cdot$ & خودانكيزشى \\
\hline.$- / 9 V$ & $\cdot / 49$ & V/Ar & $r r / A V$ & خو دنظمجويى هيجانى \\
\hline$-1 / \pi r$ &.$/ 1$ & $r \in / \pi q$ & $\mid r T / 1$. & نارسا كنشورى اجرايى \\
\hline$-1 / T r$ &.$/ 1 r$ & $9 / A r$ & $r V / 9 q$ & مشكلات دروننمود \\
\hline$-1 / r F$ & $\cdot / 4$ & $11 / F r$ & rr/ar & مشكلات بروننمود \\
\hline
\end{tabular}

$$
\begin{aligned}
& \text { براى تعيين رابطه سبك هاى والدگرى، تنيدگى والدين، و نارسايى } \\
& \text { در كنشهاى اجرايى كودكان در مشكلات دروننمودو بروننمود از } \\
& \text { همبستكى بيرسون استفاده شدكه نتايج آن در جدول بائ ارائه شده است. }
\end{aligned}
$$

\begin{tabular}{|c|c|c|c|c|c|c|c|c|c|c|c|c|c|c|}
\hline $1 \varepsilon$ & ir & it & 11 & 1. & 9 & $\wedge$ & $\checkmark$ & 7 & 0 & $\varepsilon$ & $r$ & r & 1 & متغير \\
\hline & & & & & & & & & & & & & 1 & 1. والدگرى مثبت \\
\hline & & & & & & & & & & & & 1 & $-\cdot / \Delta 9^{* *}$ & r. تنبيه بدنى \\
\hline & & & & & & & & & & & 1 & $-\cdot /\left.\Delta\right|^{* * *}$ & $\cdot / \wedge r^{* * *}$ & r. مشار كت يدر \\
\hline & & & & & & & & & & 1 & $\cdot / r^{* * a}$ & $-\cdot / \Gamma \Delta^{* \omega}$ & $\cdot / F F^{\text {* }}$ & F \\
\hline & & & & & & & & & 1 & $-\cdot / 4 q^{* * a}$ & $-\cdot / A r^{*}$ & $\cdot / V \cdot * *$ & $-\cdot / \mathrm{M}^{* * *}$ & هـ اقتدار \\
\hline & & & & & & & & 1 & $\cdot / \mathrm{V} \Lambda^{* * *}$ & $-\cdot / \pi 4^{* *}$ &.$- / 90^{* a}$ & $\cdot 190^{* * *}$ & $-\cdot / 99^{* * *}$ & 9. نظارت ضعيف \\
\hline & & & & & & & 1 & $\cdot / \Lambda \cdot * *$ & $\cdot / N F^{* * *}$ & $-\cdot / \Gamma \Delta^{* *}$ & $-.190^{\circ}$ & $\cdot / V^{\text {*** }}$ & $-\cdot 19 \Lambda^{* *}$ & V. Vنيدگى V \\
\hline & & & & & & 1 & $\cdot / \Delta V^{* s}$ & $\cdot / N^{* \infty}$ & $\cdot|q|^{* \infty s}$ & $-\cdot / r)^{* *}$ & $-\cdot / \mu r$ & $\cdot / 4 q^{\text {畨 }}$ & $-\cdot / \Upsilon \Lambda^{* * *}$ & ^ــ مديريت زمان \\
\hline & & & & & 1 & $\cdot / 9 Y^{* *}$ & $\cdot / V \Lambda^{* *}$ & $\cdot / N r^{* \infty}$ & $\cdot / \Delta r^{* * *}$ & $-\cdot / 19^{* *}$ & $-\cdot / \Delta 9^{*}$ & $\cdot / \Delta r^{\text {क⿻丷木 }}$ & $-\cdot / \Delta r^{* * *}$ & 9. حل مسأله \\
\hline & & & & 1 & $\cdot / \Delta \Lambda^{* * *}$ & $\cdot / 9 V^{* * *}$ & $\cdot / 4 r^{* * a}$ & $\cdot|9|^{* *}$ & $\cdot / 9^{* * * 6}$ & $-\cdot / Y^{* * *}$ & $-\cdot / \mu / *$ & $\cdot / q^{* * *}$ & $-\cdot / \mathrm{N}^{* * *}$ & • ا. مهار خود. \\
\hline & & & 1 & $\cdot /\left.\right|^{* * * n}$ & $\cdot /\left.\Delta\right|^{* * *}$ & $\cdot / v \cdot * *$ & $\cdot / \Delta \Delta^{* * *}$ & $\cdot|9|^{* * *}$ & $\cdot / \& \Delta^{* * * * 8}$ & $-\cdot / \Upsilon \Lambda^{* * *}$ & $-\cdot /\left.4\right|^{* * *}$ & 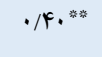 & $-\cdot / \Gamma \cdot * *$ & 11 ا. خودانگيزشى \\
\hline & & 1 & $\cdot / Y V^{* * *}$ & $\cdot / 19^{* * *}$ & $\cdot / Y I^{* * *}$ & $\cdot / \mu F^{* * *}$ & $\cdot / Y \Lambda^{* * *}$ & $\cdot / T \Lambda^{* * *}$ & $\cdot / r q^{* * * a}$ & $-\cdot / \cdot V^{* *}$ & $-\cdot / Y V^{*}$ & $\cdot / Y V^{* * *}$ & $-\cdot / \Lambda^{* * *}$ & r ا. خودنظم جويى هيجانى \\
\hline & 1 & 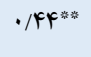 & $\cdot / V \Delta^{* * *}$ & $\cdot / I^{* * *}$ & $\cdot|\wedge|^{* * *}$ & $\cdot / 9 Y^{* * *}$ & $\cdot / V Y^{* * a}$ & $\cdot|\Lambda|^{* * *}$ & $\cdot / \Delta \Delta^{* * * 8}$ & $-\cdot / \Upsilon \varphi^{* * *}$ & $-\cdot|\Delta|^{* *}$ & $\cdot / \Delta V^{* * *}$ & $-\cdot / \mathcal{A} \boldsymbol{F}^{* * *}$ & سا. نارسايى دركنش اجرايى \\
\hline 1 & $\cdot / \Lambda \uparrow^{* * *}$ & $\cdot / \mu q * *$ & $\cdot 194 *$ & $\cdot / \Delta 9^{* * *}$ & $\cdot / V^{* *}$ & $\cdot / V \cdot * *$ & $\cdot / V V^{* s}$ & $\cdot / \Lambda \cdot * s$ & $\cdot / V \Delta^{* * *}$ & $-\cdot / \Gamma I^{* *}$ & $-\cdot /\left.\Lambda\right|^{* *}$ & $\cdot / V^{* * *}$ & $-\cdot / V \cdot * *$ & Fأ. مشكلات دروننمود \\
\hline$\cdot / 90^{* *}$ & $\cdot / Q^{* * *}$ & $\cdot / \mu \cdot * *$ & $\cdot 19 \cdot * *$ & $\cdot 19 \cdot{ }^{* a n}$ & $\cdot / N r^{* *}$ & $.190^{* *}$ & $\cdot / V^{* *}$ & $\cdot / \Lambda F^{* *}$ & $\cdot / \mathrm{V} \Lambda^{* * *}$ & $-\cdot / \pi 4^{* *}$ & $-\cdot / \wedge \kappa^{*}$ & $.194^{\text {* }}$ & $-\cdot / \sqrt{ } 9^{* *}$ & 1ه ـ مشكلات بروننمود \\
\hline
\end{tabular}

\section{جدول ץ: ماتريس همبستكى بين متغيرهاى يزوهش}

درونتمود با تنبيه بدنى ( •//)، اقتدار (VD/•)، نظارت ضـعيف ( •/•)،

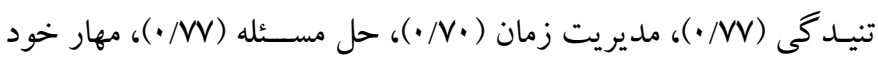

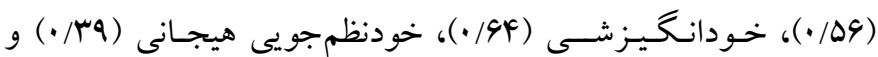

بـا توجه به نتايج جدول r، رابطه مشـكلات دروننمود با والدگرى

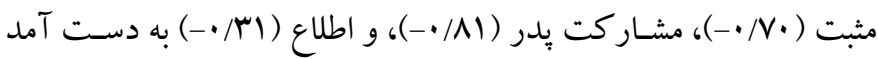

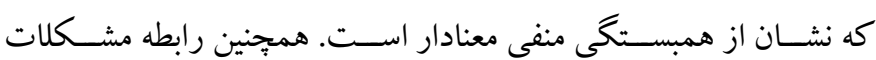




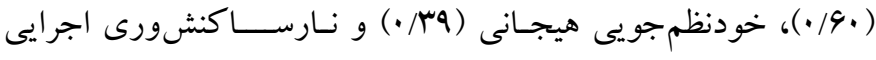

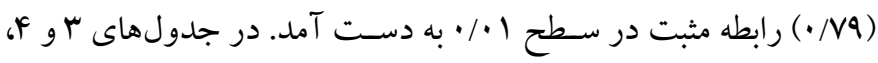

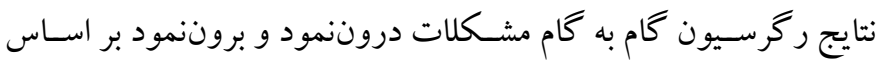

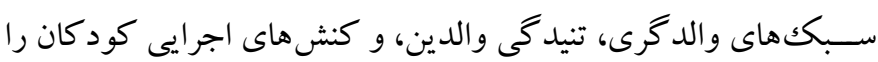
نشان مىدهد.
نارسـاكنشورى اجرايى (AF/•) مثبت معنادار در سـطح 1 • • به دسـت

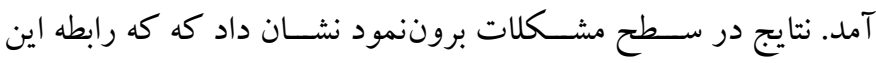

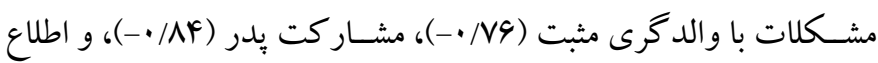

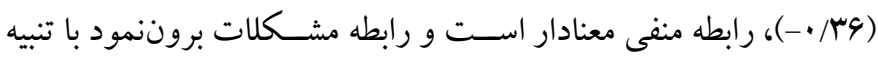

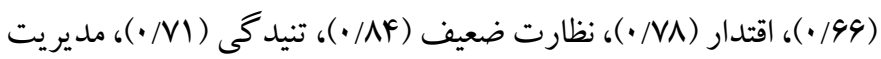

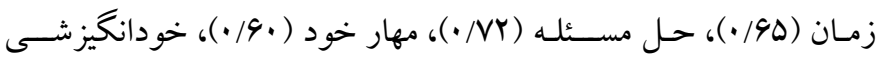

جدول ": خلاصه مدل ركر سيون، تحليل واريانس و مشخصههاى آمارى ركرسيون ييشبينى مشكلات دروننمود كود كان بر اساس متغيرهاى ييشيين

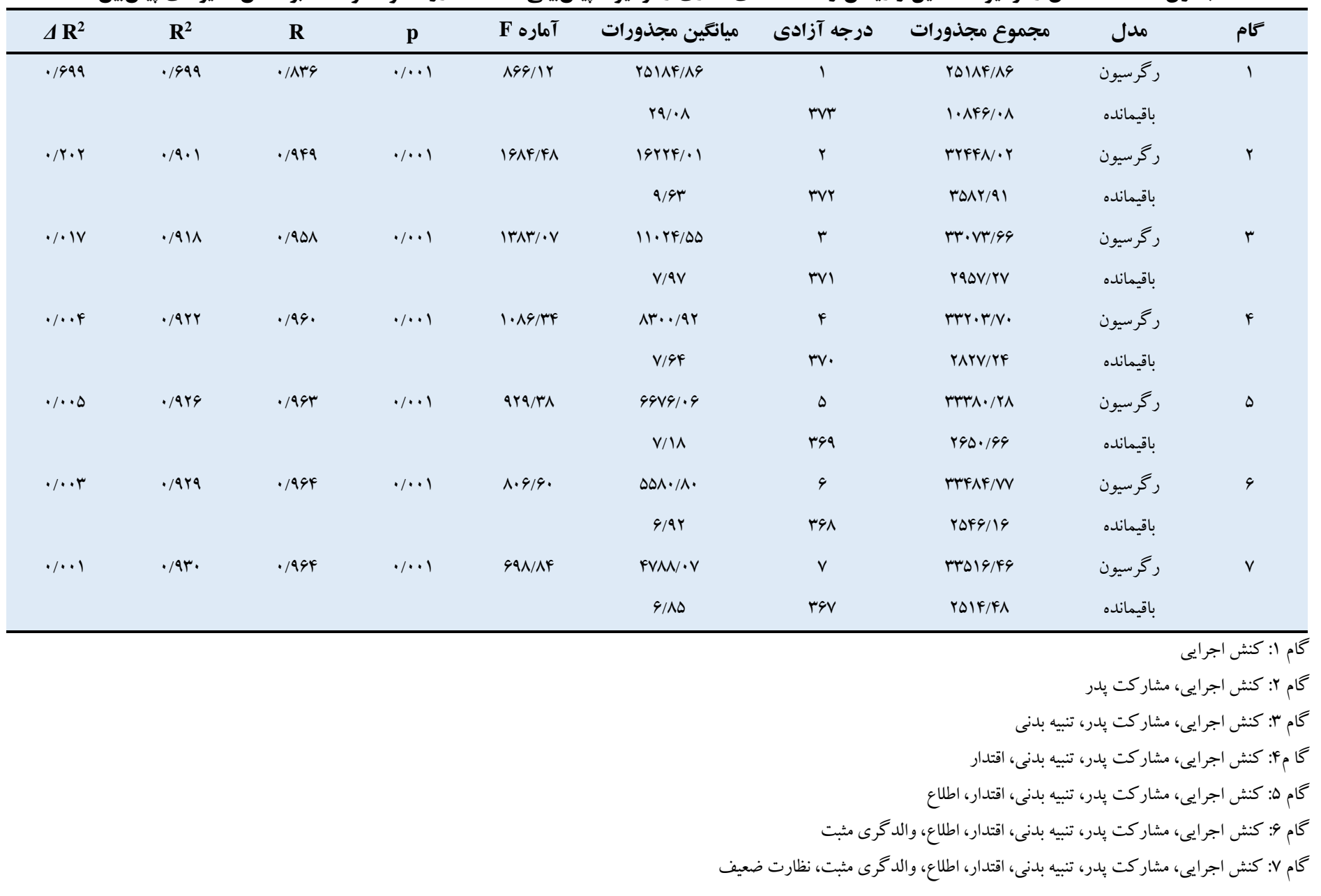

ييشبينى كردند. ميزان F مشاهده شده براى متغيرهاى بيشبين در سطح

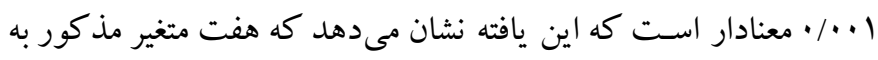

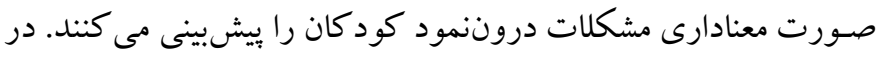

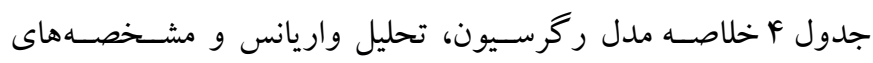
آمارى رگرسيون مشكلات برون جمود كود كان بر متغيرهاى بيشبين مدرين
بر اسـاس نتايج جدول سا، مىتوان نتيجه گرفت در تبيين مشـكلات دروننمود كود كان، مجموع متغيرهاى بيشبين ساه درصد از متغير ملاكك

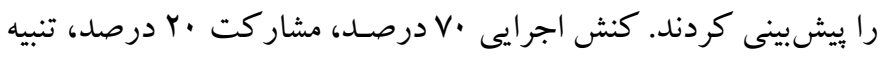

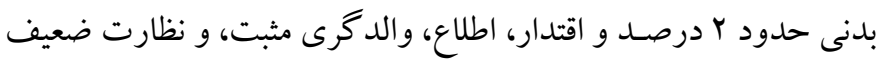

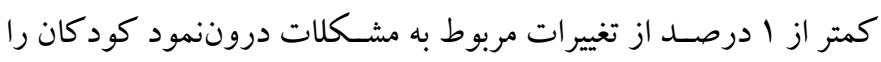


جدول ع: خلاصه مدل ركرسيون، تحليل واريانس و مشخصههاى آمارى ركرسيونيشيينى مشكلات بروننمود كودكان بر اساس متغيرهاى بيشبين

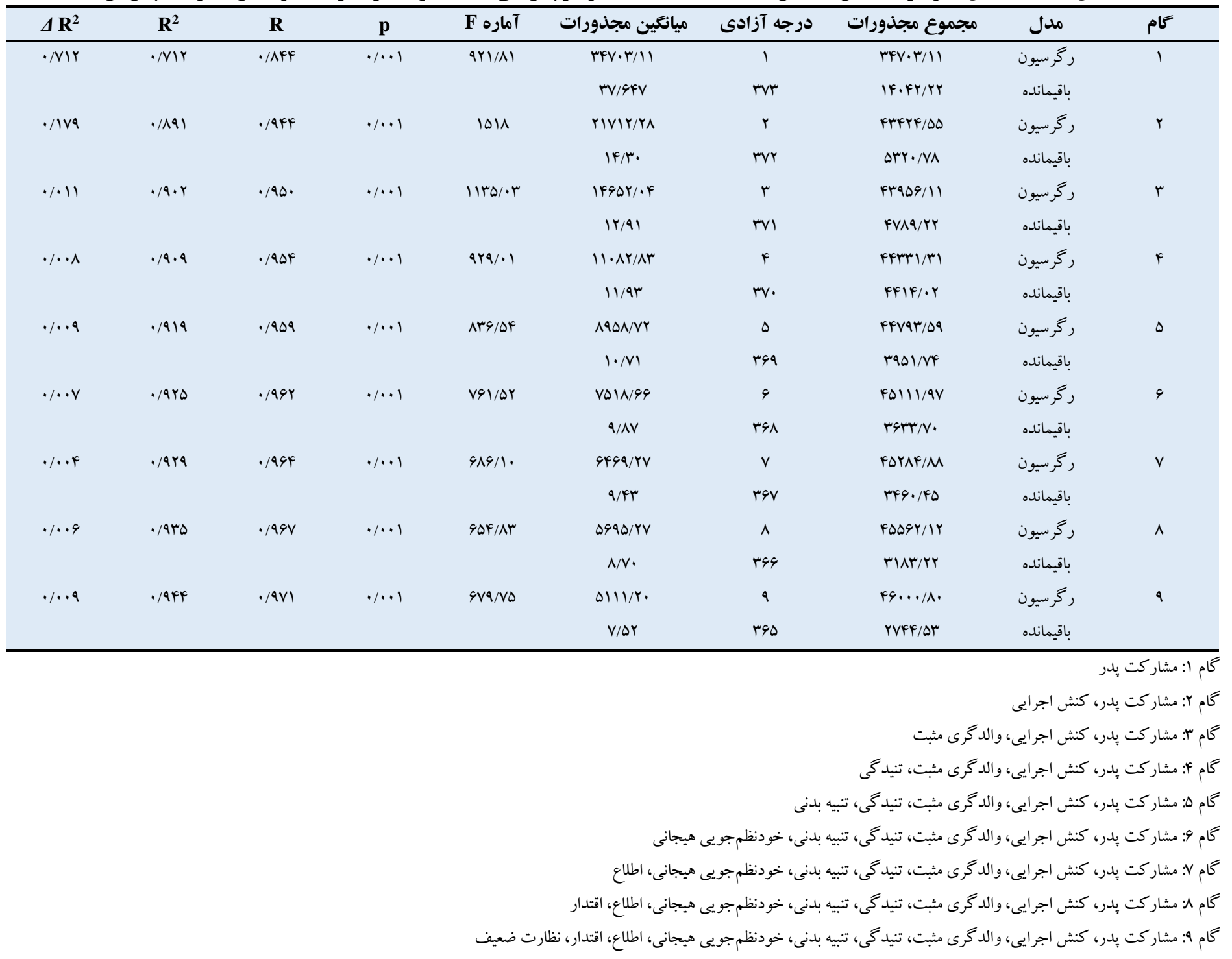

\section{بحث و نتيجه تيرى}

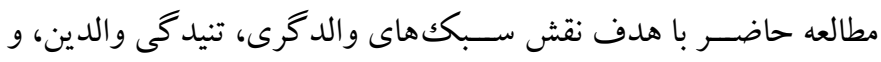

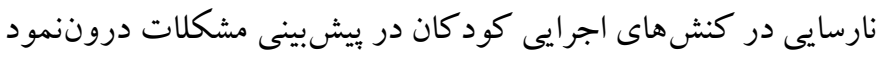

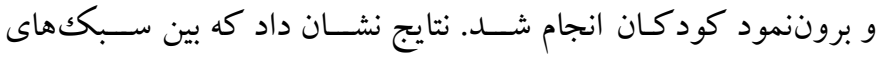
والد گرى و مشــكلات درونتمود كود كان، همبســتخى معنادارى وجود

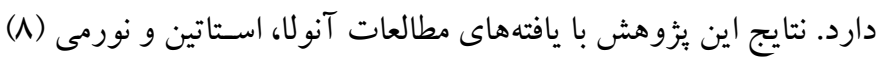

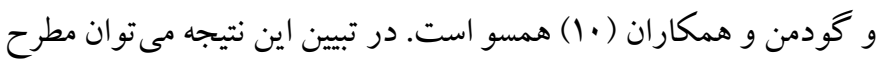

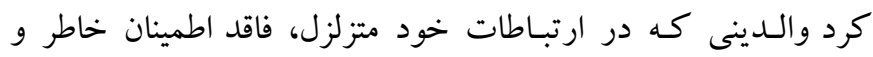

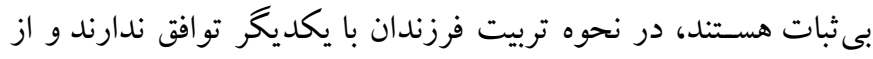

بر اسـاس جدول F مى توان نتيجه گرفت در تبيين مشكلات بروننمود

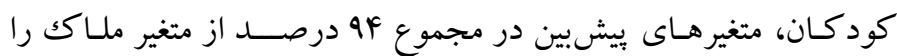

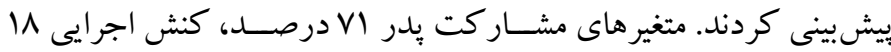

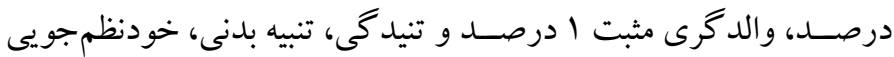

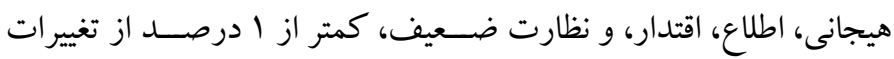

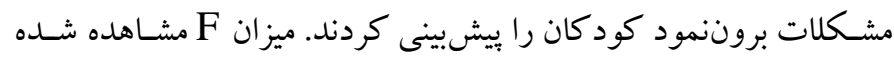

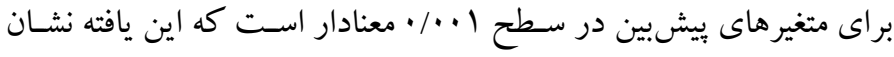

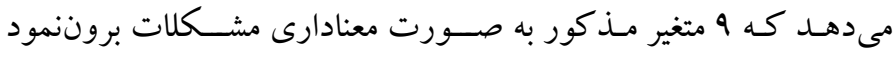
كود كان را يِيشينى مى كنند. 
تصـميم گيرى درباره مناسـبـترين راهبردهاى درمانى براى كودك،

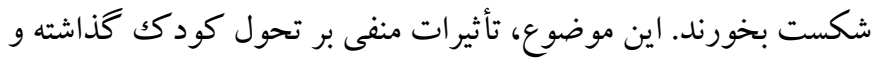

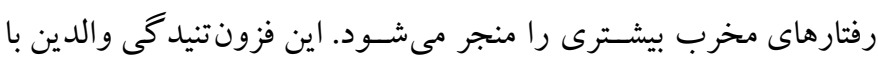

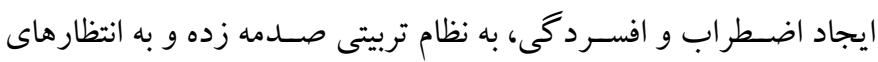
غيرواقع نخر از كود كك منجر مى شود (14).

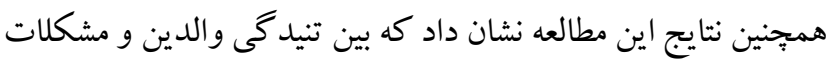

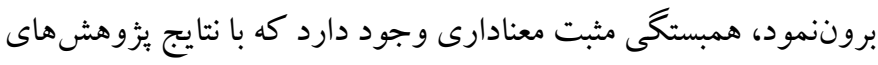

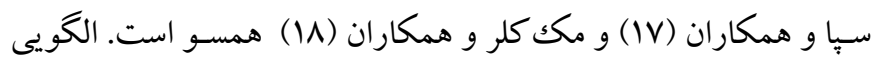
كه والدين به خصـوص مادران از ابراز هيجانى مناسـب و سـازشيافته وهانه (آزادانه نشـان دادن دامنه كسـتردهاى از هيجانها) به فرزندان ارائه مىدهنـد، به كود كان در شــناسـايى يردازش علائم هيجانى، ارتباط

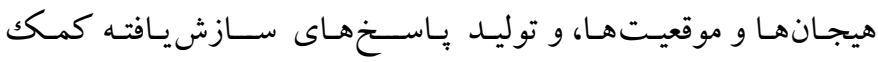

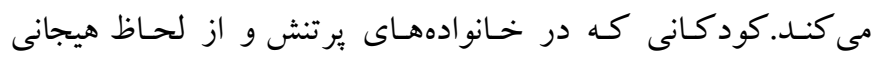

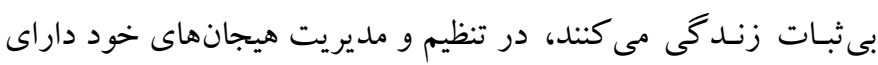

$$
\text { مشكلات عمدهاى هستند ( ب. (Y). }
$$

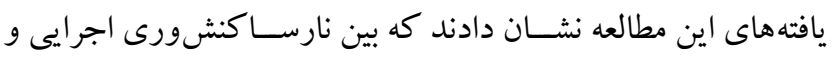

مشــكلات درون مونود كود كان، همبســتخى مثبت معنادارى وجود دارد.

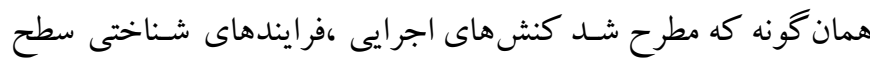

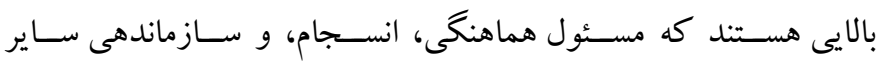

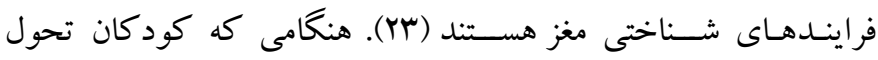
مى يابند به دليل افزايش يافتن توانايى آنها براى مديريت رفتار خود،

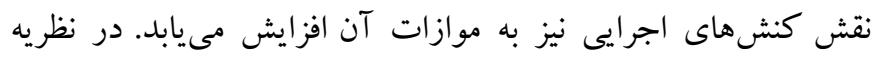

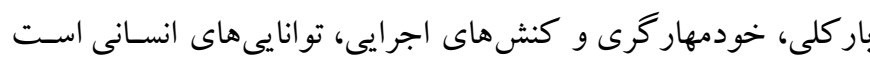
كـه با هم تعامل دارند. در اين نظريه، كنشهاى هاى اجرايى خودنظمده

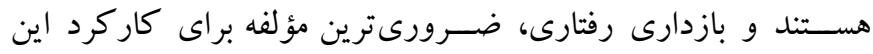
كنشها محسـوب مىشـود. دليل اين موضسوع آن اسـت كه بازدارى

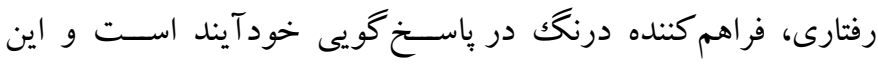

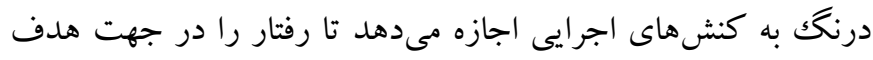

هدايت كنند (YF).

اين بززوهش نشـان داد كه بين نارسـاكنشورى اجرايى و مشـكلات

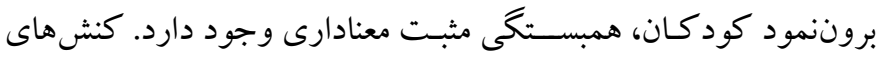

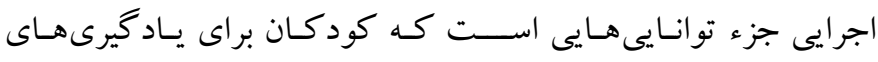

سبكك والدگرى مبتنى بر طرد حمايت افراطى با اغماض يا تسلط، شيوه

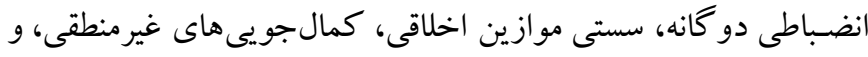

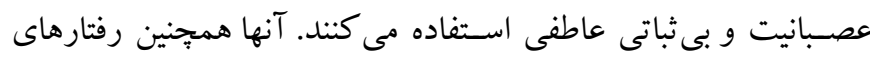

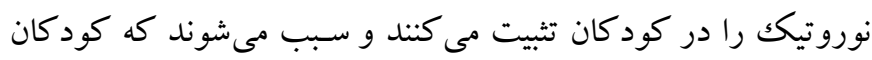

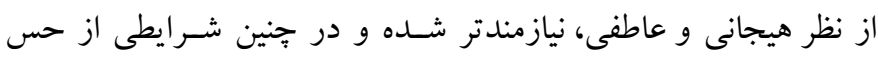

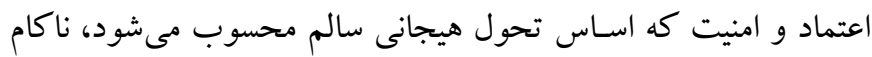

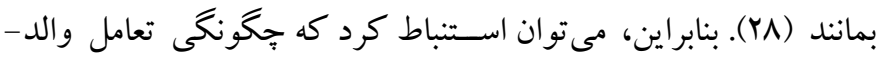

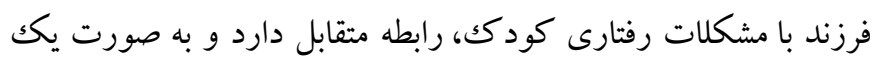

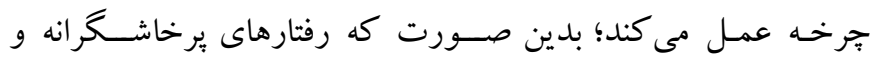

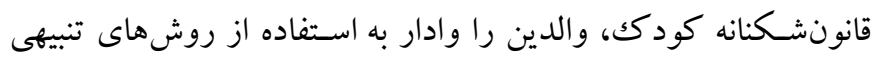
بيشترى مى كند كه اين به نوبه خود برخوردها و تعارضاتى را در رابطه

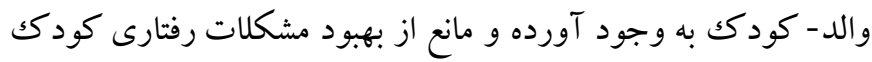

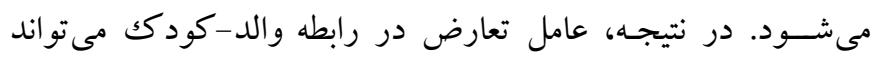
مشكلات دروننمود را ايجاد كند.

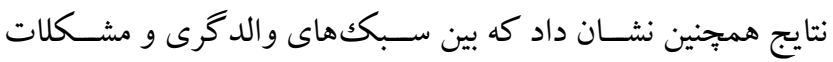

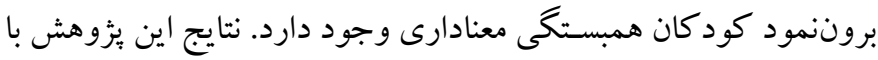

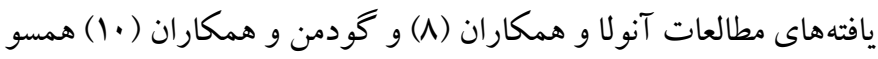

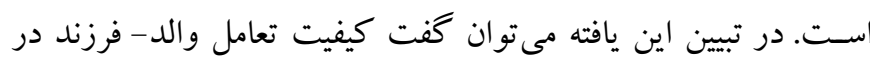

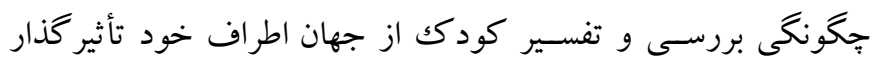

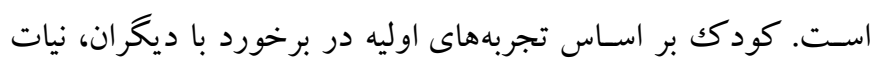
آنها را تفسير مى كند؛ بدين گونه كه وقتى كودكى تجربه تهاى اوليه

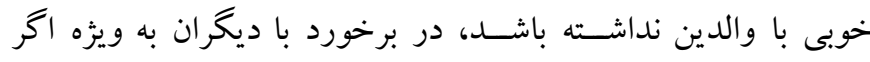

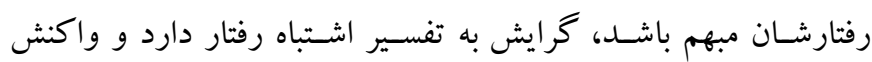

خصمانه نشان مىدهد (11). يـافتـه ديخر مطـالعه نشــان داد كه بين تنيدكى و الدين و مشــكلات دروننمود كودكـان، همبسـتخى مثبت معنادارى وجود دارد؛ به عبارت

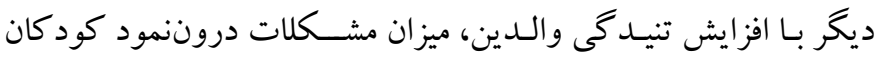

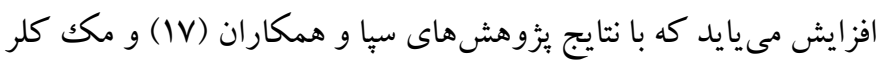

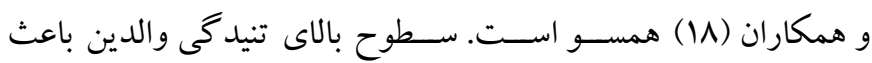

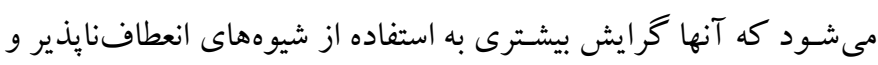

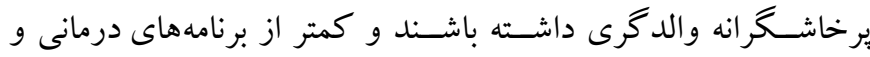
خـدمـات ارائه شــده براى كود كانشــان بهره ببرند، و از اين رو در 
دانش آموزان يســر مقطع ابتـدايى بود و همجنين در اين مطـالعه جهـت

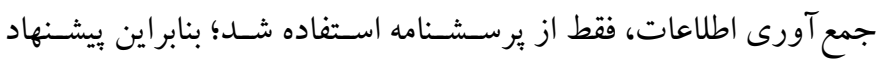

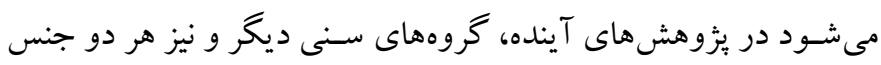

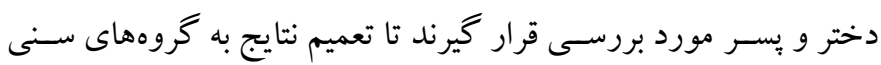

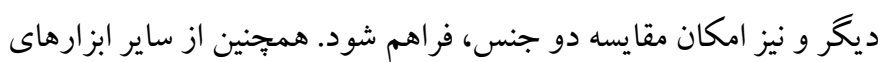

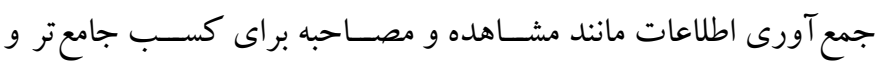

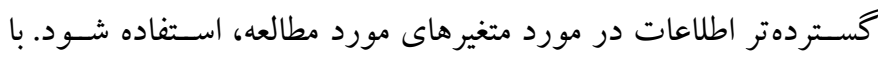
توجه به نتايج حاصل از يزوهش، ييشنهاد مى شـود جلسات و دورههاى

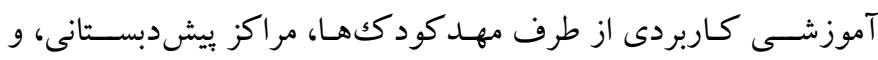
مدارس درباره سبككهاى والدگرى بر گزار شود تا آكاهى والدين درباره اين شيوهها و تأثير آن بر اختلالات رفتارى فرزندان، افزيش ايش يابد. همجنين

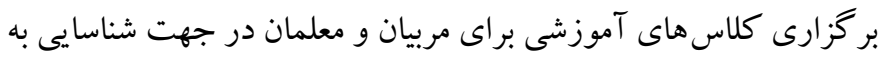

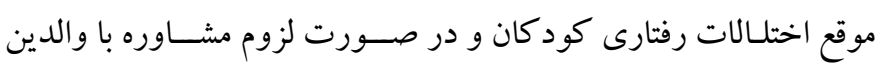

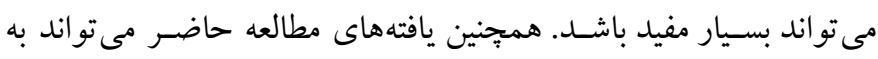

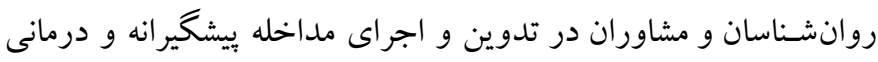
مؤثر در زمينه اختلالات رفتارى كودكان با تمركز بر متغيرهاى مطرح شده در اين يُروهش، كمكك قابل توجهى كند.

تشـكر و قدردانى: اين بثزوهش بر گرفته از بايانانامه كارشـناسى ارشـــ خانم

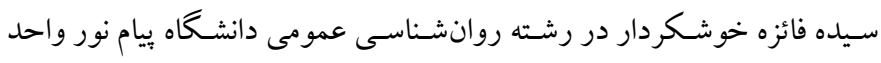

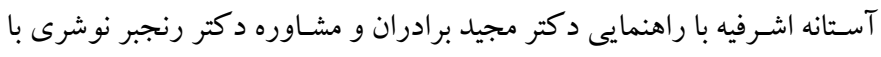

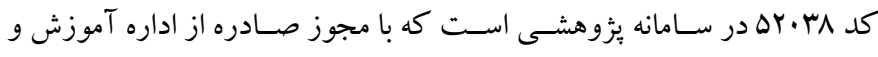

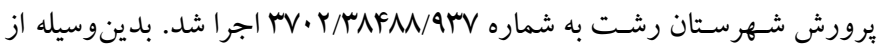

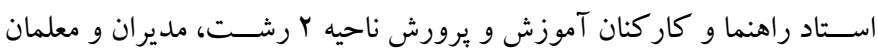
دلسوز، و تمامى افراد نمونه كه در اجراى اين يُوهش مشاركت داشتند، تشكر

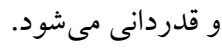

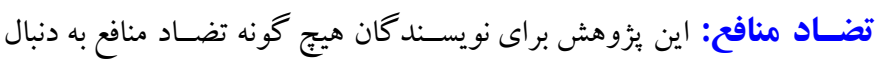
نداشته است.
مدرسـهاى، انجام فعاليت هاى روزانه، و تكاليف مدرسه به آنها نيازمندند.

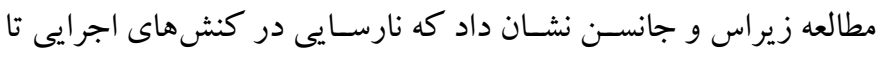
حدود زيادى بيشبينى كننده عملكرد تحصـيلى و رفتارى دانش آموزان اسـت (Y\&). با اسـتناد به اين مطالب مى توان به اهميت كنشهاى اجر ايى

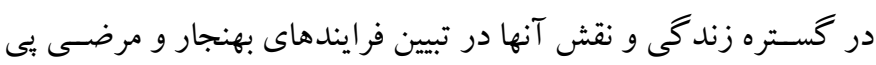

سـرانجام يافته ديخر اين بثوهش نشـان داد كه مشكلات درونتمود و

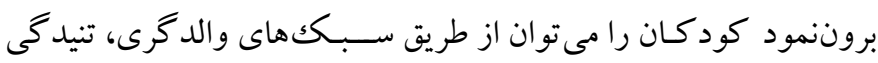
والدين، و كنشهاى اجرايى ييش بينيكرد. آنجه مسـلم اسـت مشكلكلات

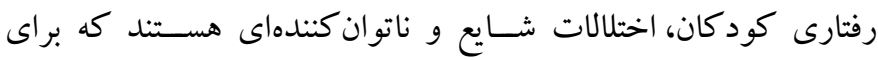
معلمـان، خـانواده، و كودكان مشـكلات بسـيارى را ايجاد مى كنند.

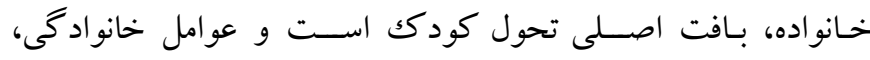

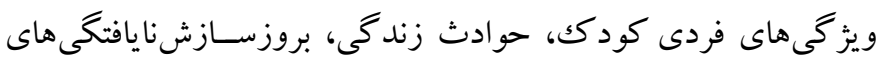

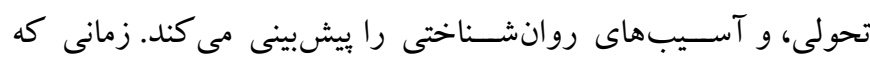

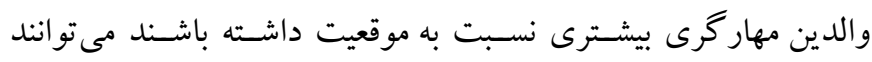

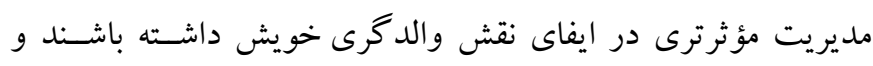
بدون اينكه مجبور باشند در مورد مقررات خود با فرزندانشان مجادله

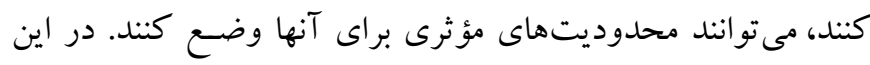

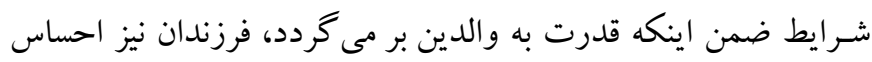

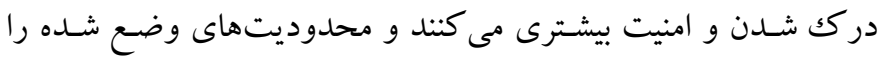

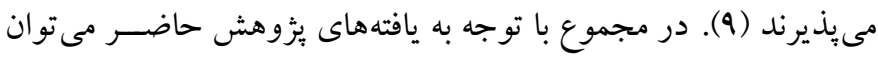

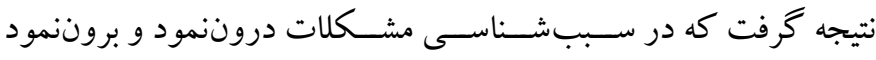

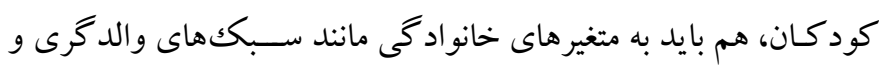

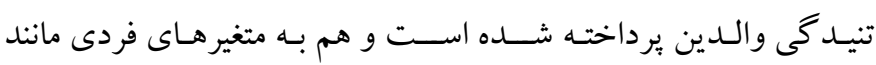

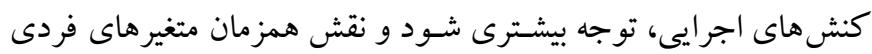

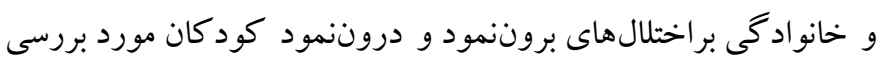

$$
\text { بيشتر قرار كيرد. }
$$

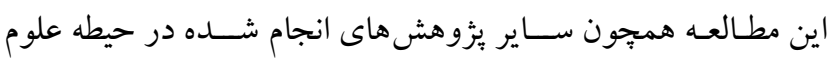
انسـانى، داراى محدوديتهايى بود. نمونه يزووهش حاضـر، فقط شـامل 


\section{References}

1. Bornstein MH, Britto PR, Nonoyama-Tarumi Y, Ota Y, Petrovic O, Putnick DL. Child development in developing countries: introduction and methods. Child Dev. 2012; 83(1): 16-31. [Link]

2. Crawford NA, Schrock M, Woodruff-Borden J. Child Internalizing Symptoms: Contributions of Child Temperament, Maternal Negative Affect, and Family Functioning. Child Psychiatry Hum Dev. 2011; 42(1): 53-64. [Link]

3. Kessler RC, Berglund P, Demler O, Jin R, Merikangas $\mathrm{KR}$, Walters EE. Lifetime prevalence and age-ofonset distributions of DSM-IV disorders in the national comorbidity survey replication. Arch Gen Psychiatry. 2005; 62(6): 593-602. [Link]

4. Ghobari-Bonab B, Parand A, Hossein Khanzadeh Firoozjah A, Movallali G, Nemati S. Prevalence of Children with Behavioral Disorders in Primary Schools in Tehran. JOEC. 2009; 9(3): 223-238. [Persian]. [Link]

5. Khoddam H, Medanloo M, Ziaie T, Keshtkar AA. Behavioral disorders and some related factors in school-age children in Gorgan. Nursing Research. 2008; 4(14): 29-37. [Persian]. [Link]

6. Carpenter AL, Puliafico AC, Kurtz MS, Pincus DB, Comer JS. Extending Parent-Child Interaction Therapy for Early Childhood Internalizing Problems: New Advances for an Overlooked Population. Clin Child and Fam Psychol Rev. 2014; 17(4): 340-356. [Link]

7. Bagheri Sheykhangafshe F, Shabahang R, Abolghasemi A. Prediction of the food neophobia by dimensions of personality and parenting styles. Quarterly Journal of Child Mental Health. 2018; 5(2): 25-35. [Persian]. [Link]

8. Aunola K, Stattin H, Nurmi J. Parenting styles and adolescents, achievement strategies. J Adolesc. 2000; 23(2): 205-222. [Link]

9. Matejevic M, Jovanovic D, Ilic M. Patterns of Family Functioning and Parenting Style of Adolescents with Depressive Reactions. Soc Behav Sci. 2015; 185: 234239. [Link]

10. Goodman SH, Rouse MH, Connell AM, Broth MR, Hall CM, Heyward D. Maternal depression and child psychopathology: A meta-analytic review. Clin Child Fam Psychol Rev. 2011; 14(1): 1-27. [Link]

11. Murray KW, Dwyer KM, Rubin KH, Knighton-Wisor S, Booth-LaForce C. Parent-child relationships, parental psychological control, and aggression: maternal and paternal relationships. J Youth Adolesc. 2014; 43(8): 1361-73. [Link]

12. Zakirova VG, Gaysina GI, Raykova E. Professional Support for Families in Difficult Life Situations. International J Env Scie Ed. 2016; 11(5): 633-639. [Link]

13. Rankin Williams L, Degnan K, Perez-Edgar K.E. Henderson H.A, Rubin K.H, Pine D.S, Steinberg L, Fox NA. Impact of Behavioral Inhibition and Parenting Style on Internalizing and Externalizing Problems from Early Childhood through Adolescence. J Abnorm Child Psychol. 2009; 37(8): 1063-1075. [Link]

14. Rollè L, Prino L.E, Sechi C, Vismara L, Neri E, Polizzi C, ... Brustia P. Parenting stress, mental health, dyadic adjustment: A structure equation model. Front Psychol. 2017; 8: 839-845. [Link]

15. Teymouri S, Ataeifar R. Relationship between parental stress and children's affective and behavioral disorders. Journal of Clinical Psychology Andishe va Raftar. 2010; 4(16): 17-26. [Persian]. [Link]

16. Crawford AM, Manassis K. Familial predictors of treatment outcome in childhood anxiety disorders. J Am Acad Child Adoles Psych. 2001; 40(10): 11821189. [Link]

17. Sepa A, Frodi A, Ludvingsson J. Could parental stress and lack of support/confidence function as mediating mechanisms between certain environmental factors and the development of autoimmunity in children? A study within ABIS. Annals of the New York Academy of Science. 2002; 958: 431-435. [Link]

18. Mackler JS, Kelleher R, Shanahan L, Calkins SD, Susan P, Keane SP, O'Brien M. Parenting Stress, Parental Reactions, and Externalizing Behavior From Ages 4 to 10. J Marriage Fam. 2016; 77(2): 388-406. [Link]

19. Khaleque A, Rohner RP. Perceived parental acceptance-rejection and psychological adjustment: A meta-analysis of cross-cultural and intercultural studies. J Marriage Fam. 2002; 64(1): 54-64. [Link]

20. Putnick DL, Bornstein MH, Hendricks C, Painter KM, Suwalsky JTD, Collins WA. Stability, continuity, and similarity of parenting stress in European American mothers and fathers across their child's transition to adolescence. Parent Sci Pract. 2010; 10: 60-77. [Link]

21. Tottenham N, Hare TA, Casey BJ. Behavioral assessment of emotion discrimination, emotion regulation, and cognitive control in childhood, adolescence, and adulthood. Front Psychol. 2011; 2, 1-9. [Link] 
22. Brown TE. Executive Functions and Attention Deficit Hyperactivity Disorder: Implications of two conflicting views. International J Disability, Dev Ed. 2006; 53(1): 35-46. [Link]

23. Kooij SJJ, Huss M, Asherson P, Akehurst RRR, Beusterien K, French A, Sasané R, Hodgkins P. Distinguishing Comorbidity and Successful Management of Adult ADHD. J Atten Disord. 2012; 16(5): 3-19. [Link]

24. Barkley RA. Behavioral inhibition, sustained attention, and executive functions: Constructing a unifying theory of ADHD. Psychol Bull. 1997; 121(1): 65-94. [Link]

25. Skirrow C, Asherson P. Emotional lability, comorbidity and impairment in adults with attentiondeficit hyperactivity disorder. J Affect Disord. 2013; 147(1): 80-86. [Link]

26. Ziereis S, Jansen P. Effects of physical activity on executive function and motor performance in children with ADHD. Res Dev Disabi. 2015; 38: 181-191. [Link]

27. Dadds MR, Maujean A, Fraser J A. Parenting and conduct problems in children: Australian data and psychometric properties of the Alabama Parenting Questionnaire. Australian Psychologist. 2003; 38(3): 238-241. [Link]

28. Samani S. Psychometric properties of the child from of Alabama Parenting Questionnaire (Persian version). Journal of Psychological Models and Methods. 2011; 2(5): 17-29. [Persian]. [Link]
29. Dadsetan P, Ahmadi Azghandi A, Hassan Abadi H. Parental stress and general health: research on the relationship between parenting stress of mothers with general health nurses and housewives with young children. Developmental Psychology Journal: Iranian psychologists. 2006; 2(7): 184-171. [Persian]. [Link]

30. Knouse LE, Barkley RA, Murphy KR. Does executive functioning $(\mathrm{EF})$ predict depression in clinic-referred adults? EF tests vs. rating scales. J Affect Disord. 2013; 145(2): 270-275. [Link]

31. Mashhadi A, Mirdoraghi F, Hosainzadeh-Maleki Z, Hasani J, Hamzeloo M. Factor Structure, Reliability and Validity of Persian Version of Barkley Deficits in Executive Functioning Scale(BDEFS)- Adult Version. Journal of Clinical Psychology. 2015; 7(1): 51-62. [Persian]. [Link]

32. McCarty CA, Lau AS, Valeri SM, Weisz JR. ParentChild interactions in relation to critical and emotionally overinvolved Experessed Emotion (EE): is EE a proxy for behavior? J Abnorm Child Psychol, 2004; 32: 83-93. [Link]

33. Nakamura BJ, Ebesutani C, Bernstein A, Chorpita BF. A psychometric analysis of the Child Behavior Checklist DSM-oriented Scales. J Psychopathol Behav Assess. 2009; 31(3): 178-189. [Link]

34. Minaei A. Adaptation and Standardization of the child behavior checklist Akhen bakh, self-assessment questionnaire and teacher report form. Research in exceptional children. 2006; 6(1): 529-558. [Persian]. [Link] 